Nataliia Bashavets,

Doctor of Pedagogy, professor, Department of Socio-Humanitarian Disciplines, Odessa Trade and Economic Institute of Kyiv National University of Trade and Economics, 6, 25 Chapaievskoi Divizii Str., Odesa, Ukraine

\title{
CURRENT FEATURES OF PHYSICAL TRAINING OF UNIVERSITY STUDENTS AND RECOMMENDATIONS FOR ITS IMPROVEMENT
}

The formation of post-industrial society and innovative changes in young peoples' occupation and rest, the transformation of the Ukrainian society affect the quality characteristics of physical culture. So it is quite natural that recent years in Ukraine are characterized by the active development of models of organization of physical training of university students. The most promising area of physical training optimization at higher educational institutions is searching for the creative and pedagogical educational model based on the international experience, which involves the humanization of subject-content basis, socio-cultural integration, professionally-oriented focus, the selectivity according to sports specialization, innovation activity of a teacher and the individualization of the educational process. The article is aimed at identifying the features of physical training of students at higher educational institutions basing on the review of the international experience and providing recommendations for its improvement. The review of the international experience in the organization of physical education makes it possible to identify different approaches to this process. It is quite clear that physical training is of the great importance in many countries because future graduates have to be highly skilled professionals with the high level of physical fitness. Under the current conditions higher educational institutions should implement a professionally-focused model of physical training organization (for $1^{\text {st }}-3^{\text {rd }}$ year students) in the form of mandatory physical classes in study time (1 day a week), extracurricular activities and recreational sports classes for students with health problems (twice a week) and for physical classes healthy students -2 times a week. $4^{\text {th }}-5^{\text {th }}$ year students should be engaged into individual and sectional elective physical classes. The chosen by an educational institution model of physical training organization should contribute to the increasing of motor activity of students, improving of their physical and mental working capacity. It should have positive impact on students' academic results; make them attend physical training classes with pleasure, do physical exercises at home in extracurricular time, etc.

Keywords: physical education, model, student, higher educational institution, pedagogical process.

Подано до редакиії 04.04.2016

Рецензент: д. мед. н., проф. О. П. Романчук

УДК: 615.322-613.65

Елена Валерьевна Бобро, кандидат медииинских наук, дочент кафедры биологии и основ здоровья, Сергей Дмитриевич Неделев, студент 3 курса факультета физической реабилитаичи, Южноукраинский национальный педагогический университет имени К. Д. Уиинского, ул. Старопортофранковская, 26, г. Одеса, Украина

\section{ВОЗМОЖНОСТЬ ПРИМЕНЕНИЯ ОБЩЕМЕДИЦИНСКИХ ЗНАНИЙ} СТУДЕНТАМИ ФАКУЛЬТЕТА ФИЗИЧЕСКОГО ВОСПИТАНИЯ

Статья посвящчена обоснованию возможности расширения общемедицинских знаний студентов факультета физического воспитания с иелью повышения эффективности здоровьезаберегающих технологий, которье используются в учебном процессе на примере изучения природных веществ, способствующих восстановлению здоровья. Вещества биогеоорганического происхождения способствуют нормализации биохимических прочессов и физиологических функций организма; в силу своего происхождения повышают уровень адаптаџии и качество систем обеспечения жизнедеятельности. Отмечено, что за период использования адаптогенов в практике выявлена возможность их применения в комплексе с другими лечебными средствами. Природные адаптогены не обладают токсическим эффектом даже при длительном воздействии на организм. Представляет интерес дальнейшее определение влияния препаратов биогеоорганического происхождения на различные функциональные системы организма при интенсивных физических нагрузках.

Ключевые слова: адаптация, обучение, физическая нагрузка, синдром «перетренированности».

Постановка проблемы. Сохранение здоровья при физических и эмоционально-психических нагрузках является актуальной задачей. Еще в конце XX века предполагалось, что длительные занятия спортом способствуют накоплению физических и психических сил, которые можно расходовать на активную социальную жизнь. Однако одной из причин нарушения здоровья даже у спортсменов студенческого возраста на фоне длительной и интенсивной физической активности может быть развитие синдрома «перетренированности» - ответная психо-физиологическая реакция организма на чрезмерную тренировочную нагрузку. Данный синдром является комплексным и имеет ряд индивидуальных особенностей. Поскольку окон- 
чательно не определен набор лабораторных исследований, позволяющих выявить начинающийся или скрытый синдром «перетренированности» при отсутствии надлежащего медицинского контроля, можно говорить о нем как о причине развития разнообразных патологических состояний. Отмечено, что состояние «перетренированности» на начальном этапе редко отличают от обыкновенной усталости. Субъективно он может характеризоваться ощущением, когда требуется больше усилий для выполнения обычной тренировки, увеличивается период восстановления между подходами. Даже обычная студенческая деятельность может вызывать раздражение. Если режим студента-спортсмена не меняется, наблюдается возникновение инфекционных заболеваний: например, «банальное ОРЗ», что свидетельствует о нарушениях иммунной системы. В дальнейшем возможно присоединение патологии внутренних органов. Внешне такое состояние будет проявляться нарушением сна, усталостью, депрессией и местными симптомами заболевания.

Помимо этого специалисты столкнулись с еще одной проблемой. Даже если общее физическое состояние студента-спортсмена удовлетворительное, отмечены случаи, когда при тестировании выявляется следующее: календарный возраст опережает биологический. Это приводит к преждевременному старению организма и истощению адаптационных возможностей будущего спортсмена. Таким образом, для поддержания организма студента факультета физической культуры на должном физиологическом уровне целесообразен поиск разнообразных природных факторов, которые обладают положительным эффектом восстановления функциональной активности органов и систем и разрешены к применению для спортсменов.

Анализ последних исследований и публикаций. Определением соответствия биологического и календарного возраста студентов занимается Н. М. Гаврилова. Комплексную диагностику физического состояния студентов проводит М. И. Попичев. Состояние здоровья студенческой молодежи исследует Е. И. Перова. Оценкой физической подготовленности студентов занимается С. В. Хотиенко. Мотивационный подход к управлению физическим воспитанием студентов исследует Т. Ю. Круцевич.

Изучению положительного влияния природных факторов уделено немало внимания вследствие их адекватного воздействия на адаптационные механизмы организма человека в любом возрасте. Выявлением возможности обеспечения биоактивации регуляторных систем данными препаратами занимается И. С. Чекман, П. Г. Царфис. Коррекцию состояния здоровья при помощи природных факторов проводят: В. В. Арьков, И. В. Бакаев, Л. А. Ботвинева. О. Ю. Верба, Г. А. Горчакова, В. П. Михайлов и др. Изучают вещества биогеоорганического происхождения для восстановления физиологической активности различных органов и систем организма в НИИ глаз- ных болезней и тканевой терапии (г. Одесса) Е. П. Сотникова, В. И. Иванов, А. Б. Абрамова, Т. Д. Лотош, Б. Н. Соколова и др.

Цель статьи - обосновать необходимость расширения общемедицинских знаний студентов факультета физической культуры на примере поиска веществ природного происхождения, обеспечивающих саногенные влияния на организм в условиях интенсивных физических и эмоционально-психических нагрузок.

Методы исследования: общенаучные методы теоретического уровня - аналогия, анализ, синтез, индукция, абстрагирование, системнофункциональный анализ.

Изложение основного материала. В процессе обучения в ВУЗе студенты факультетов физического воспитания осваивают ряд дисциплин профессиональной направленности, совмещая обучение со спортивной деятельностью. Таким образом, молодой организм подвергается нагрузкам и сверхнагрузкам разного вида - в результате нарушение адаптационных возможностей организма и формирование комплекса профессиональных заболеваний. Однако студенты данной специализации обязаны получить знания, умения и навыки здорового активного образа жизни и уметь передать их ученикам в школе. Будущий учитель физкультуры должен не столько привести вверенных ему школьников к спортивным достижениям, сколько укрепить их здоровье и главное - научить детей следить за своим физическим состоянием: фактически сформировать полезные навыки и привычки на всю жизнь. Для этого разработаны методики проведения физкультурных и физкультурнооздоровительных уроков у школьников разных возрастных групп [2]. Помимо этого, существуют методы проведения целенаправленных занятий с лицами разного пола и возраста. Студенты факультетов физического воспитания накапливают знания, имеющие прямое отношение к восстановлению и укреплению физического здоровья у лиц всех возрастных групп с различным первоначальным состоянием. В этом им немало помогает изучение дисциплин медикобиологической направленности.

В частности, в курсе общих медицинских знаний студенты получают информацию о сохранении здоровья в разнообразных, опасных для жизни состояниях, о способах первичной диагностики и методах оказания первой помощи. При этом выполняются основные задачи курса:

- проведение просветительской деятельности в среде студенческой молодежи;

- формирование ценностного отношения к собственному здоровью и здоровью окружающих;

- обучение навыкам оказания первой помощи в неотложных состояниях.

Все требования соответствуют современным реалиям, так в статье 32 Закона Украины «Про охорону здоров'я» отмечено: «держава сприяє утверджен- 
ню здорового способу життя населення шляхом розповсюдження наукових знань 3 питань охорони здоров'я, організації медичного, екологічного і фізичного виховання» [3].

Однако необходимо расширять объем знаний в данной области и знакомить студентов с различными методиками поддержания здоровья, в том числе и в стрессовых ситуациях, при длительных физических нагрузках. В частности ознакомить с методиками восстановления при помощи различных природных факторов, информация о которых может быть представлена комплексно:

- история возникновения фактора,

- общий механизм действия,

- область применения.

Это следует рассмотреть на примере ознакомления студентов с факторами биогеоорганического происхождения, способствующих восстановлению здоровья.

Так к группе природных факторов биогеоорганического происхождения, относятся биогенные адаптогены, полученные методом тканевой терапии, впервые разработанные академиком В. П. Филатовым. Биогенными адаптогенами являются вещества, противодействующие гибели ткани, попавшей в условия, неблагоприятные для ее существования (например, пониженная температура). В данном случае пониженная температура обуславливает качественную перестройку в метаболитных системах, соответственно изменение привычных физиологических процессов, в результате чего и происходит повышение жизнеспособности организма. Перестройка происходит в ферментных системах, появляется новое свойство: когда потребность в дополнительной энергии для активирования молекул в реакции, катализируемой такими ферментами, становится меньше. Биогенные стимуляторы - не ферменты, но, возникая, они влияют на метаболические процессы в тканях, видимо, через ферменты. Таким образом, неблагоприятные условия переживания обуславливают, в результате изменения биохимических процессов, накопление, кроме полезных веществ, большого числа карбоновых кислот и аминов. Примером тканевых препаратов является «Торфот» - приготовляемый из торфа, в его состав входят органические вещества, способные перегоняться с водяным паром. Также к группе природных факторов относят пелоиды и препараты на их основе. Согласно современной классификации, к пелоидам относятся и торфяные грязи. Торфяные грязи - болотные отложения, особенности образования которых связывают с избыточным увлажнением при недостатке кислорода. Химический состав торфа зависит от растений-торфообразователей. Торфы, отличающиеся высокой кислотностью, обладают заметной бактерицидностью. Кислотность лечебных грязей определяется кислыми солями металлов - сульфатов железа, алюминия. Показано, что щелочные виды торфов стимулируют функцию надпочечников, а кислые ви- ды - угнетают. В нативных грязях содержатся гормоноподобные вещества, антибиотики, биогенные стимуляторы, микроэлементы, органические кислоты, растворенные ионы газов; особо следует выделить роль микроорганизмов, участвующих в переработке растительных остатков. Органическое вещество торфов в результате биохимических реакций превращается в аминосоединения: летучие амины, летучие фенолы, летучие жирные кислоты и углеводы. Применение торфов обусловлено их абсорбционной способностью поглощать патогенную флору; наличием гуминовых веществ и разнообразных микроэлементов, обладающих высокой биологической активностью. Общими механизмами, характерными для позитивного воздействия пелоидов, считают их органоминеральный состав. При поиске источников гееоганических стимуляторов проводится методический подход к оценке качества исходного вещества. Все они, несмотря на различие материала, содержат органические кислоты. Вместе с тем есть вещества, по которым препараты различаются. Так, летучие амины «Торфота» и пелоидодистиллата не могут находиться в препаратах растительного происхождения, например, алоэ. Различие тканевых препаратов по химическому составу может быть также связано с особенностями метаболизма исходной ткани. Этот индивидуальный метаболизм при пониженной температуре и служит основой для качественно и количественно различных метаболитов. Большое внимание было уделено изучению химического состава тканевых препаратов, в частности, определено наличие ряда аминокислот, микроэлементов, витаминов, карбоновых и непредельных кислот.

Поскольку все тканевые препараты производятся по уникальным технологиям из натурального сырья, сохранение физиологически активных веществ максимальное. Являясь естественными метаболитами, адаптогены легко проникают через биологические барьеры и участвуют в физологических реакциях организма. За время открытия и внедрения в клиническую практику тканевых препаратов было проведено немало экспериментальных исследований. Отрицательное влияние тканевых препаратов на сердечнососудистую систему при длительном влиянии на сердце, сосуды, кровяное давление отсутствует. При исследовании пищеварительной системы в эксперименте проявлено стимулирующее влияние «Торфота» и экстракта алоэ на сократительную способность гладкой мускулатуры кишечника. В дальнейшем было определено, что тканевые препараты не обладают гистаминоподобным действием и не являются апирогенными [4]. На модели экспериментального гепатита отмечено уменьшение развития соединительнотканных элементов при применении тканевой терапии. Проводились исследования по одновременному применению адаптогенов с другими лекарственными веществами. Установлено, что предварительное введение тканевых препаратов закономерно повышает сопротивляемость 
организма токсическим дозам любых лекарственных веществ. Было выявлено повышение выживаемости экспериментальной группы животных в условиях моделирования острого иммобилизационно-холодового стресса в структурах головного мозга при применении «Торфота». Поскольку экспериментальные исследования различных препаратов выявили их некоторую однотипность действия, то довольно часто авторы не акцентируют внимание на происхождении исследуемого объекта. Положительный эффект от применения тканевых препаратов исследовался в экспериментальных работах и подтвержден практическим применением.

Исследованию эффективности тканевых препаратов большое внимание уделял А. А. Зелинский, определивший их вазотропный эффект. Широкое применение нашла практика тканевой терапии при лечении нервных болезней: радикулиты различного генеза - в результате нарушения обменных процессов, травматического, инфекционного.

В ходе экспериментальных исследований была выявлена возможность коррекции дизрегуляционной судорожной активности головного мозга при использовании препарата геоорганического происхождения «Торфот». Отмечено, что предварительное введение «Торфота» предотвращает нарастание тяжести судорожных реакций [1].

Еще на заре развития тканевой терапии гистологические исследования показали, что тканевые адаптогены замедляют развитие раневого процесса, способствуют снижению воспаления, усиливают пролиферацию новых тканей в ране. Интенсивно восстанавливаются нервные окончания, и разрастается новая грануляционная ткань. При воздействии на специфические ткани выявлено быстрое восстановление сердечной мышцы: при экспериментальном миокардите отмечается уменьшение дисторофических и склеротических изменений. Также замечено усиление регенерации трубчатых костей и ускорение формирования костной мозоли при травмах.

Таким образом, вещества биогеоорганического происхождения обладают разнообразным заживляющим, стимулирующим действием, используются при восстановлении всех систем организма. Было выявлено, что природные адаптогены способствуют восстановлению адаптационных механизмов и способствуют реабилитации спортсменов с синдромом «перенапряжения» [4]. Разнообразие эффектов можно объяснить механизмом действия подобных веществ. Существуют две основные теории взаимодействия организма и биостимулятора. Физическая - изменения происходят при воздействии на кожные покровы и слизистые; и химическая действие метаболита при применении во внутрь. Так использование подобных препаратов внутрь приводит к активизации адаптационно-трофической функции симпатической нервной системы, что проявляется в ускорении окислительно-восстановительных процессов, усилении и облегчении перехода кислорода к тканям и усиленному выведению углекислоты, происходит активизация клеточного дыхания. Активизация биохимических процессов ведет к уменьшению содержания недоокисленных продуктов и восстановлению физиологических функций. В результате улучшаются реологические свойства крови, происходит усиление микроциркуляции органа или системы органов. Соответственно, использование препаратов для восстановления той или иной системы организма благотворно сказывается как на работе данной системы, так и на всех физиологических функциях в целом.

Клинические и экспериментальные данные свидетельствуют о целесообразности сочетания тканевых адаптогенов с витаминами, антибиотиками и другими медикаментозными препаратами [5], в результате чего эффективность терапии и реабилитации усиливается, так как в силу своего происхождения биогеоорганические метаболиты более физиологичны и близки организму по своему составу. Однако следует помнить, что препараты данной группы являются стимуляторами физиологических процессов и хаотическое их использование может привести к бесконтрольной активации систем организма, в частности излишней стимуляции работы желудочно-кишечного тракта при приеме внутрь.

Таким образом, в результате изучения дисциплин медико-биологической направленности студент получает комплексные знания о развитии, строении, функционировании организма человека в разные возрастные периоды, при различных состояниях и нагрузках, а также знания о часто встречающихся патологических состояниях и возможностях восстановления здоровья различными природными факторами.

Выводы и перспективы дальнейших исследований. Как свидетельствует анализ научных данных, вещества биогеоорганического происхождения способствуют активизации адаптационно-трофической функции вегетативной нервной системы, нормализации биохимических процессов и соответственно физиологических функций; повышают уровень адаптации организма и качество систем обеспечения жизнедеятельности. Они представляют интерес для ознакомления студентовспортсменов в курсе общемедицинских знаний для их использования в период восстановления после травм, повреждений и заболеваний с целью сохранения здоровья. В дальнейшем предполагается выявление влияния препаратов биогеоорганического происхождения на различные функциональные системы организма при интенсивных физических нагрузках. 


\section{ЛИТЕРАТУРА}

1. Бобро Е. В. Изучение энцефалотропного действия «Торфота» применением ЭЭГ (ЭКоГ)-метода / Е. В. Бобро // Сборник трудов ЛГАУ. - 2004. - № 39 (51). - C. 80-83.

2. Іващенко Л.Я. Методика фізкультурнооздоровчих занять. / Л.Я. Іващенко, Т.Ю. Круцевич. Київ: УДУФВС, 1994. - 126 с.

3. Законодавчі акти України з питань освіти / Верховна Рада України. Комітет з питань науки і освіти: Офіц.вид. - К.: Парламентське вид-во, 2004. - 404 с.

4. Прошин Д. Г. Влияние природных антиокси-

\section{REFERENCES}

1. Bobro, E. V. (2004). Izuchenie entsefalotropnogo deystviya «Torfota» primeneniem EEG (EKoG)-metoda [Studying of entcephalotrophic action of "Torfot" application of EEG (EKOG) - method]. Sbornik trudov LGAU Collection of works of LGAU, 39 (51), 80-83 [in Russian].

2. Ivaschenko, L.Ya. \& Krutsevich, T.Yu. (1994). Metodika fIzkulturno-ozdorovckhyh zaniat [Methods of sports and remedial training]. Kyiv: UDUFVS [in Ukrainian].

3. Zakonodavchi akty Ukrainy z pytan osvity [Legislative Acts of Ukraine on Education]. (2004). Verkhovna Rada Ukrainy. Komitet z pytan nauky i osvity: Ofits.vyd. Verkhovna rada of Ukraine. The Committee on Science and Education: The official publication. Kyiv: Parlamentske vyd-vo [in Ukrainian]. дантов при реабилитации спортсменов с острым физическим перенапряжением / Д. Г. Прошин, А.Г. Чиж // Иммунореабилитация и реабилитация в медицине, III международный конгресс, 4-7 мая. 1997 г.: тезисы. - Эйлат. - Т 167. - № 4. - С. 195-196.

5. Сотнікова О. П. Перспективи розробки і застосування тканинних препаратів / О. П. Сотнікова // Фармакологія 2006 крок у майбутнє : III національний з'їд фармакологів України, 17-20 жовт. 2006 р. : тези допов. - Київ. - Х., 2006. - С. 162-163.

4. Proshin, D. G. (1997). Vliyanie prirodnykh antioksidantov pri reabilitatsii sportsmenov s ostryim fizicheskim perenapryazheniem [Influence of natural antioxidants for rehabilitation of athletes with sharp physical overstrain]. Immunoreabilitatsiya $i$ reabilitatsiya $v$ meditsine - Proceedings of the $3^{\text {rd }}$ international congress «Immunorehabilitation and rehabilitation in medicine» (pp. 195-196). Eylat [in Russian].

5. Sotnikova, O. P. (2006). Perspektivy rozrobky i zastosuvannia tkanynnykh preparativ [Prospects of the development and application of tissue preparations]. Farmakologiia 2006 krok u maybutnie - Proceedings of the $3^{\text {rd }}$ national Congress of pharmacologists of Ukraine international congress "Pharmacology 2006 step into the future» (p.p. 162). Kyiv [in Ukrainian].

\section{Олена Валеріївна Бобро, кандидат медичних наук, доцент кафедри біологї̈ та основ здоров'я, Сергій Дмитрович Неделев,} студент 3-го курсу факультету фізичної реабілітачії, Південноукраїнський національний педагогічний університет імені К. Д. Уиинського, вул. Старопортофранківська, 26, м Одеса, Украӥна

\section{МОЖЛИВІСТЬ ЗАСТОСУВАННЯ ЗАГАЛЬНОМЕДИЧНИХ ЗНАНЬ СТУДЕНТАМИ ФАКУЛЬТЕТУ ФІЗИЧНОГО ВИХОВАННЯ}

Стаття присвячена обгрунтуванню можливості розширення загальномедичних знань студентів факультету фізичного виховання з метою підвищення ефективності здоров'язберігаючих технологій, що застосовуються у навчальному процесі на прикладі вивчення природних речовин, які сприяють відновленню та збереженню здоров'я. При виснажливих фізичних та психоемоційних навантаженнях студентів факультетів фізичної культури доволі часто зустрічається порушення здоров'я на тлі розвитку синдрому «перевантаження». Цей синдром $\epsilon$ комплексним та має низку індивідуальних особливостей у своєму прояві. У подальшому синдром «перевантаження» може стати причиною розвитку захворювань різних систем організму. Але існують речовини природного походження, що забезпечують саногенний вплив на організм в умовах довготривалих фізичних та психоемоційних навантажень. До групи природних факторів належать препарати біогеоорганічного походження, які отримано методом тканинної терапії. Ці лікарняні форми практично не мають побічних ефектів. Клінічні та експериментальні дані свідчать про доцільність поєднання тканинних адаптогенів у комплексі 3 вітамінами, антибіотиками та іншими лікарняними формами. Ефективність курсу тільки підвищується внаслідок того, що біоорганічні метаболіти близькі за складом до живих організмів та є більш фізіологічними за інші препарати. Було встановлено, що природні адаптогени сприяють відновленню адаптаційних механізмів та якнайшвидшої реабілітації спортсменів із синдромом «перевантаження». Ранні гістологічні дослідження показали, що сповільнюється розвиток ранового процесу, зменшується запалення, посилюється проліферація нових тканин, та відновлюються нервові закінчення, посилюється регенерація трубчастих кісток, а також прискорюється формування кісткової мозолі при травмуваннях. Як свідчить аналіз літературних даних, речовини біогеорганічного походження допомагають активізувати адаптаційно-трофічну функцію вегетативної нервової системи; 
нормалізують біохімічні процеси та фізіологічні функції організму; підвищують рівень адаптованості та якість систем забезпечення життєдіяльності. Це дає можливість застосування їх у період відновлення після травм, ушкоджень та 3 метою відновлення здоров'я спортсменів. У подальшому передбачається вивчити вплив препаратів біоорганічного походження на різні системи організму при довготривалих фізичних навантаженнях.

Ключові слова: адаптація, здоров'язберігаючі технології, навчання, фізичне навантаження, синдром «перетренування».

Olena Bobro,

PhD (Candidate of Medical Sciences), associate professor, Department of Biology and Foundations of Health,

Serhii Nedelev,

$3^{\text {rd }}$ year student, Faculty of Physical Rehabilitation, South Ukrainian National Pedagogical University named after K. D. Ushynsky, 26, Staroportofrankivska Str., Odesa, Ukraine

\section{POSSIBILITY OF USING GENERAL MEDICAL KNOWLEDGE} BY STUDENTS MAJORING IN PHYSICAL TRAINING

The article deals with the issue of studying natural substances which promote recovery of health. It will help to expand the general medical knowledge of students majoring in Physical culture and apply them in their practical activities. Preservation of health in case of long physical, emotional and mental activities of students majoring in Physical culture is considered to be an urgent issue today. A lot of health problems can be caused by the syndrome of overload, which in turn leads to visceral diseases. The syndrome of overload can cause a lot of diseases. Violations of cardiovascular, bronchopulmonary systems and digestive tract belong to the most often-observed problems in the health of sportsmen. In order to maintain an organism of a sportsman in a good physiological state various natural factors having a positive impact on the restoration of functional activity of organs are to be found and examined. A lot of attention is paid to the studying of positive influence of natural factors because they adequately influence the adaptable mechanisms of a human body and provide the biological activation of regulatory systems. The article is aimed at justifying the search for the naturally-occurring substances, which provide the sanogenic influence on the human body under the conditions of long-term physical and psycho-emotional loads. The group of naturally-occurring substances involves products of biological origin produced by means of the method of tissue therapy. As a rule they do not have side effects. Clinical and experimental results speak for the expediency of using tissue adaptogenes together with vitamins, antibiotics and other drugs. The efficiency of the course increases due to the fact that bioorganic metabolites are similar by the formulae with living bodies and are more physiological than other drugs. It has been established that natural adaptogenes contribute to the restoration of adaptation mechanisms and fast rehabilitation of sportsmen who suffer from the overload syndrome. They help to activate the adaptive and nutritional functions of the vegetative nervous system; normalize the biochemical processes and physiological functions; increase the level of adaptedness, etc. It allows using them during the rehabilitation period in order to restore sportsmen's health.

Keywords: adaptation, health-saving technologies, teaching, physical activity, syndrome of overload.

Рецензент: д. мед. н., проф. О. П. Романчук

Подано до редакиії 04.04.2016 